\title{
REVIEW
}

\section{Clinical Review: Gene-based therapies for ALI/ARDS: where are we now?}

\author{
James Devaney', Maya Contreras ${ }^{1,2}$ and John G Laffey',2,3*
}

\begin{abstract}
Acute lung injury (ALI) and acute respiratory distress syndrome (ARDS) confer substantial morbidity and mortality, and have no specific therapy. The accessibility of the distal lung epithelium via the airway route, and the relatively transient nature of ALI/ ARDS, suggest that the disease may be amenable to gene-based therapies. Ongoing advances in our understanding of the pathophysiology of ALI/ARDS have revealed multiple therapeutic targets for genebased approaches. Strategies to enhance or restore lung epithelial and/or endothelial cell function, to strengthen lung defense mechanisms against injury, to speed clearance of infection and to enhance the repair process following ALI/ARDS have all demonstrated promise in preclinical models. Despite three decades of gene therapy research, however, the clinical potential for gene-based approaches to lung diseases including ALI/ ARDS remains to be realized. Multiple barriers to effective pulmonary gene therapy exist, including the pulmonary architecture, pulmonary defense mechanisms against inhaled particles, the immunogenicity of viral vectors and the poor transfection efficiency of nonviral delivery methods. Deficits remain in our knowledge regarding the optimal molecular targets for genebased approaches. Encouragingly, recent progress in overcoming these barriers offers hope for the successful translation of gene-based approaches for ALI/ARDS to the clinical setting.
\end{abstract}

\section{Background and context}

Acute lung injury (ALI) and acute respiratory distress syndrome (ARDS) constitute the leading cause of death in pediatric and adult critical care [1]. In the United States alone there are approximately 190,600 cases of

*Correspondence: john.laffey@nuigalway.ie

${ }^{2}$ Department of Anaesthesia and Intensive Care Medicine, Galway University

Hospitals, Newcastle Road, Galway, Ireland

Full list of author information is available at the end of the article
ALI/ARDS with a $40 \%$ mortality rate, amounting to 75,000 deaths annually [2]. Significant ongoing morbidity, including pulmonary, neuromuscular, cognitive and psychiatric sequelae, is seen in 50 to $70 \%$ of ALI/ARDS survivors, and the financial burden on society is considerable $[1,3]$. There are no specific therapies for ALI/ARDS, and management remains supportive, focusing on protective mechanical ventilation strategies [4], restrictive intravenous fluid management approaches [5], and rescue strategies such as prone positioning [6] or extracorporeal membrane oxygenation [7] for severely hypoxemic patients. These issues underline the need to consider nonconventional therapeutic approaches.

\section{Gene therapy: opportunities in ALI/ARDS}

Gene-based therapy involves the insertion of genes or smaller nucleic acid sequences into cells and tissues to replace the function of a defective gene, or to alter the production of a specific gene product, in order to treat a disease. Gene therapy can be classified into germline and somatic gene therapies. Germline approaches modify the sperm or egg prior to fertilization and confer a stable heritable genetic modification. Somatic gene approaches use gene therapy to alter the function of mature cells. Commonly used somatic gene therapy strategies include the overexpression of an existing gene and/or the insertion of smaller nucleic acid sequences into cells to alter the production of an existing gene.

ALI/ARDS may be suitable for gene-based therapies as it is an acute but relatively transient process [8], requiring short-lived gene expression, obviating the need for repeated therapies and reducing the risk of an adverse immunological response. The distal lung epithelium is selectively accessible via the tracheal route of administration, allowing targeting of the pulmonary epithelium [9]. The pulmonary vasculature is also relatively accessible, as the entire cardiac output must transit this circulation. Antibodies that bind antigens selectively expressed on the pulmonary endothelial surface can be complexed to gene vectors to facilitate selective targeting following intravenous administration [10]. It is also possible to use gene-based strategies to target other cells central to the pathogenesis of ALI/ARDS, such as leukocytes and 
fibroblasts [11]. Furthermore, gene-therapy-based approaches offer the potential to selectively target different phases of the injury and repair process. The potential to target specific aspects of the injury and repair processes such as epithelial-mesenchymal transition, fibrosis, fibrinolysis, coagulopathy and oxidative stress with these approaches is also clear.

\section{Current gene-based approaches}

Gene therapy requires the delivery of genes or smaller nucleic acid sequences into the cell nucleus using a carrier or vector. The vector enables the gene to overcome barriers to entry into the cell, and to make its way to the nucleus to be transcribed and translated itself or to modulate transcription and/or translation of other genes. Both viral and nonviral vector systems have been developed (Table 1).

\section{Viral vector-delivered gene therapy}

Viral vectors are the most effective and efficient way of getting larger nucleic acid sequences, particularly genes, into cells (Table 1). The viral genome is modified to remove the parts necessary for viral replication. This segment is then replaced with the gene of interest termed a transgene - coupled to a promoter that drives its expression. The modified genome is then encapsulated with viral proteins. Following delivery to the target site, the virus binds to the host cell, enters the cytoplasm and releases its payload into the nucleus (Figure 1). The size of transgene that can be used depends on the capsid size. A number of different viral vectors have been used in preclinical lung injury studies to date.

\section{Adenoviral vectors}

Adenoviruses have double-stranded DNA genomes, have demonstrated promise in preclinical models [12,13] and are well tolerated at low to intermediate doses in humans $[14,15]$. Advantages include their ease of production, the high efficiency at which they can infect the pulmonary epithelium $[14,16]$ and that they can deliver relatively large transgenes. A disadvantage of adenoviruses is their immunogenicity, particularly in repeated doses [14]. Newer adenoviral vectors, in which much of the immunogenicity has been removed, hold promise [17]. While adenovirus-mediated gene transfer in the absence of epithelial damage is relatively inefficient [18], this may be less of a problem in ALI/ARDS that is characterized by widespread epithelial damage.

\section{Adeno-associated virus vectors}

Adeno-associated viruses (AAVs) are single-stranded DNA parvoviruses that are replication deficient [19]. A substantial proportion of the human population has been exposed to AAVs but the clinical effects are unknown.
AAV vectors have a good safety profile, and are less immunogenic compared with other viruses, although antibodies do develop against AAV capsid proteins that can compromise repeat administration. AAV vectors can insert genes at a specific site on chromosome 19. The packaging capacity of the virus is limited to $4.7 \mathrm{~kb}$, restricting the size of the transgene that can be used. AAVs are less efficient in transducing cells than adenoviral vectors. Successful AAV vector gene transfer has been demonstrated in multiple lung cell types including lung progenitor cells, in both normal and naphthaleneinduced ALI lungs [20]. AAV serotypes have specific tissue tropisms, due to different capsid proteins that bind to specific cell membrane receptors. AAV-5 [21] and AVV-6 [22] exhibit enhanced tropism for the pulmonary epithelium [21,22]. AAVs can transduce nondividing cells and result in long-lived transgene expression. AAV vectors have been used in clinical trials in cystic fibrosis patients, underlining their safety profile $[23,24]$.

\section{Lentivirus vectors}

These RNA viruses can transfect nondividing cells such as mature airway epithelial cells [25]. The virus stably but randomly integrates into the genome and expression is likely to last for the lifetime of the cell ( 100 days). The transgene can be transmitted post mitosis, and there is also a risk of tumorigenesis if the transgene integrates near an oncogene. The development of leukemias in children following gene therapy for severe combined immunodeficiency highlights this risk [26,27]. While lentiviral vectors may be useful to correct a gene deficiency associated with increased risk of ALI, the long-lived gene expression of lentiviral delivered genes may be more suitable for chronic diseases than for ALI/ARDS.

\section{Nonviral gene-based strategies}

Nonviral delivery systems, while generally less efficient than viral vectors in transfecting the lung epithelium, are increasingly used to deliver smaller DNA/RNA molecules (Table 1). Strategies include the use of DNA-lipid and DNA-polymer complexes and naked DNA/RNA oligonucleotides, such as siRNA [28], decoy oligonucleotides [29] and plasmid DNA [30]. Nonviral delivery systems are less immunogenic than viral vector-based approaches, and can be generated in large amounts at relatively low cost.

\section{Plasmid transfer}

Plasmid vectors are composed of closed circles of doublestranded DNA. As naked and plasmid DNA contain no proteins for attachment to cellular receptors, there is no specific targeting to different cell types and thus it is essential that the DNA is placed in close contact with the desired cell type. These limitations make this approach less relevant clinically. 
Table 1. Gene therapy approaches used in preclinical ALI/ARDS models

\begin{tabular}{|c|c|c|c|}
\hline Approach & Advantages & Disadvantages & Examples \\
\hline \multicolumn{4}{|c|}{ Viral vector-delivered gene therapy } \\
\hline $\begin{array}{l}\text { Adenoviral vectors } \\
\text { (dsDNA genome) }\end{array}$ & $\begin{array}{l}\text { Relatively easily produced } \\
\text { Efficiently transfect lung } \\
\text { epithelium }[14,16] \\
\text { Can deliver larger genes } \\
\text { Well tolerated in lower doses }[1,3]\end{array}$ & Immunogenic [14] & $\begin{array}{l}\text { Adenoviral transfer of genes for a surfactant } \\
\text { enzyme [49], angiopoietin-1 [51], HSP-70 [52], } \\
\text { apolipoprotein A-1 [53], and } \mathrm{Na}^{+}, \mathrm{K}^{+}-\mathrm{ATP} \text { ase pump } \\
\text { [55] genes attenuate experimental ALI } \\
\text { Adenoviral delivery of IL-10 gene attenuates } \\
\text { zymosan ALI at low doses, but is harmful at high } \\
\text { doses [58] }\end{array}$ \\
\hline $\begin{array}{l}\text { Adeno-associated virus } \\
\text { vectors (ssDNA genome) }\end{array}$ & $\begin{array}{l}\text { Good safety profile; less } \\
\text { immunogenic } \\
\text { Inherently replication deficient } \\
\text { AAV-5 and AAV- } 6 \text { lung epithelial } \\
\text { tropism }[10,11] \\
\text { Transduce nondividing cells } \\
\text { Long-lived gene expression } \\
\text { Used in clinical trials for CF }[12,13]\end{array}$ & $\begin{array}{l}\text { Limited transgene size } \\
\text { Difficult to produce in large } \\
\text { quantities }\end{array}$ & $\begin{array}{l}\text { AAV vector gene transfer demonstrated in multiple } \\
\text { lung cell types including progenitor cells in both } \\
\text { normal lungs and following naphthalene-induced } \\
\text { ALI [20] }\end{array}$ \\
\hline $\begin{array}{l}\text { Lentivirus vectors } \\
\text { (RNA genome) }\end{array}$ & $\begin{array}{l}\text { Transduce nondividing cells [25] } \\
\text { Integrate stably but randomly } \\
\text { into the genome }\end{array}$ & $\begin{array}{l}\text { Oncogenesis risk due to } \\
\text { integration into genome } \\
{[26,27]}\end{array}$ & $\begin{array}{l}\text { Lentiviral transfer of shRNA to silence CD36 gene } \\
\text { expression suppresses silica-induced lung fibrosis } \\
\text { in the rat [35] }\end{array}$ \\
\hline \multicolumn{4}{|l|}{ Nonviral gene-based strategies } \\
\hline $\begin{array}{l}\text { Plasmid transfer (closed } \\
\text { dsDNA circles) }\end{array}$ & Easily produced at low cost & $\begin{array}{l}\text { No specific cell targeting } \\
\text { Very inefficient }\end{array}$ & $\begin{array}{l}\text { Electroporation-mediated gene transfer of the } \\
\mathrm{Na}^{+}, \mathrm{K}^{+} \text {-ATPase rescues endotoxin-induced lung } \\
\text { injury [60] }\end{array}$ \\
\hline $\begin{array}{l}\text { Nonviral DNA complexes } \\
\text { (lipoplexes or polyplexes) }\end{array}$ & $\begin{array}{l}\text { Complexes protect DNA } \\
\text { Complexes facilitate cellular } \\
\text { targeting [31] }\end{array}$ & Less efficient than viral vectors & $\begin{array}{l}\text { Cationic lipid-mediated transfer of the } \mathrm{Na}^{+}, \mathrm{K}^{+}- \\
\text {ATPase gene ameliorated high-permeability } \\
\text { pulmonary edema [59] } \\
\text { Lipoplex-delivered IL-10 gene decreased } \\
\text { CLP-induced ALI [61] } \\
\text { Systemic cationic polyethylenimine polyplexes } \\
\text { incorporating indoleamine-2,3-dioxygenase } \\
\text { decreased ischemia-reperfusion ALI [62] }\end{array}$ \\
\hline $\begin{array}{l}\text { DNA and RNA } \\
\text { oligonucleotides (siRNA, } \\
\text { shRNA, decoy } \\
\text { oligonucleotides) }\end{array}$ & $\begin{array}{l}\text { Easily produced at low cost } \\
\text { Smaller molecules that can } \\
\text { easily enter cells } \\
\text { Target regulation of specific genes }\end{array}$ & No specific cell targeting & $\begin{array}{l}\text { Specific siRNAs reduce inflammation-associated } \\
\text { lung injury in humans [33] and in animal models } \\
{[28,34]} \\
\text { shRNA-based approaches have reduced lung injury } \\
\text { in animal models }[35,36]\end{array}$ \\
\hline \multicolumn{4}{|l|}{ Cell-delivered gene therapy } \\
\hline $\begin{array}{l}\text { Mesenchymal stem/ } \\
\text { stromal cells }\end{array}$ & $\begin{array}{l}\text { Systemic or intrapulmonary } \\
\text { delivery } \\
\text { Strategy used in human } \\
\text { studies [41] }\end{array}$ & Relatively expensive & $\begin{array}{l}\text { MSCs expressing angiopoeitin-1 attenuate } \\
\text { endotoxin-induced ALI [40] } \\
\text { Bone marrow stem cells expressing keratinocyte } \\
\text { growth factor via an inducible lentivirus protects } \\
\text { against bleomycin-induced lung injury [66] }\end{array}$ \\
\hline Fibroblasts & $\begin{array}{l}\text { Systemic delivery } \\
\text { Less expensive }\end{array}$ & & $\begin{array}{l}\text { Fibroblasts expressing angiopoeitin-1 attenuate } \\
\text { endotoxin induced ALI [40] }\end{array}$ \\
\hline
\end{tabular}

$A A V$, adeno-associated virus; ALI, acute lung injury; ARDS, acute respiratory distress syndrome; CF, cystic fibrosis; CLP, cecal ligation and puncture; dsDNA, doublestranded DNA; IL, interleukin; MSC, mesenchymal stem/stromal cell; shRNA, small hairpin RNA; siRNA, small inhibiting RNA; ssDNA, single-stranded DNA.

\section{Nonviral DNA complexes}

The therapeutic DNA is held within a sphere of lipids, termed a lipoplex, or within a sphere of polymers, such as polyethyleneimine, termed a polyplex. Lipoplexes and polyplexes act to protect the DNA, facilitate binding to the target cell membrane and also trigger endocytosis of the complex into the cell, thereby enhancing gene expression. These systems can be modified to include a targeting peptide for a specific cell type, such as airway epithelial cells [31]. These complexes efficiently and safely transfect airway epithelial cells [31], and they have demonstrated promise in human studies [32].

\section{DNA and RNA oligonucleotides}

siRNAs are dsRNA molecules of 20 to 25 nucleotides that can regulate the expression of specific genes. Specific siRNAs reduce inflammation-associated lung injury in 


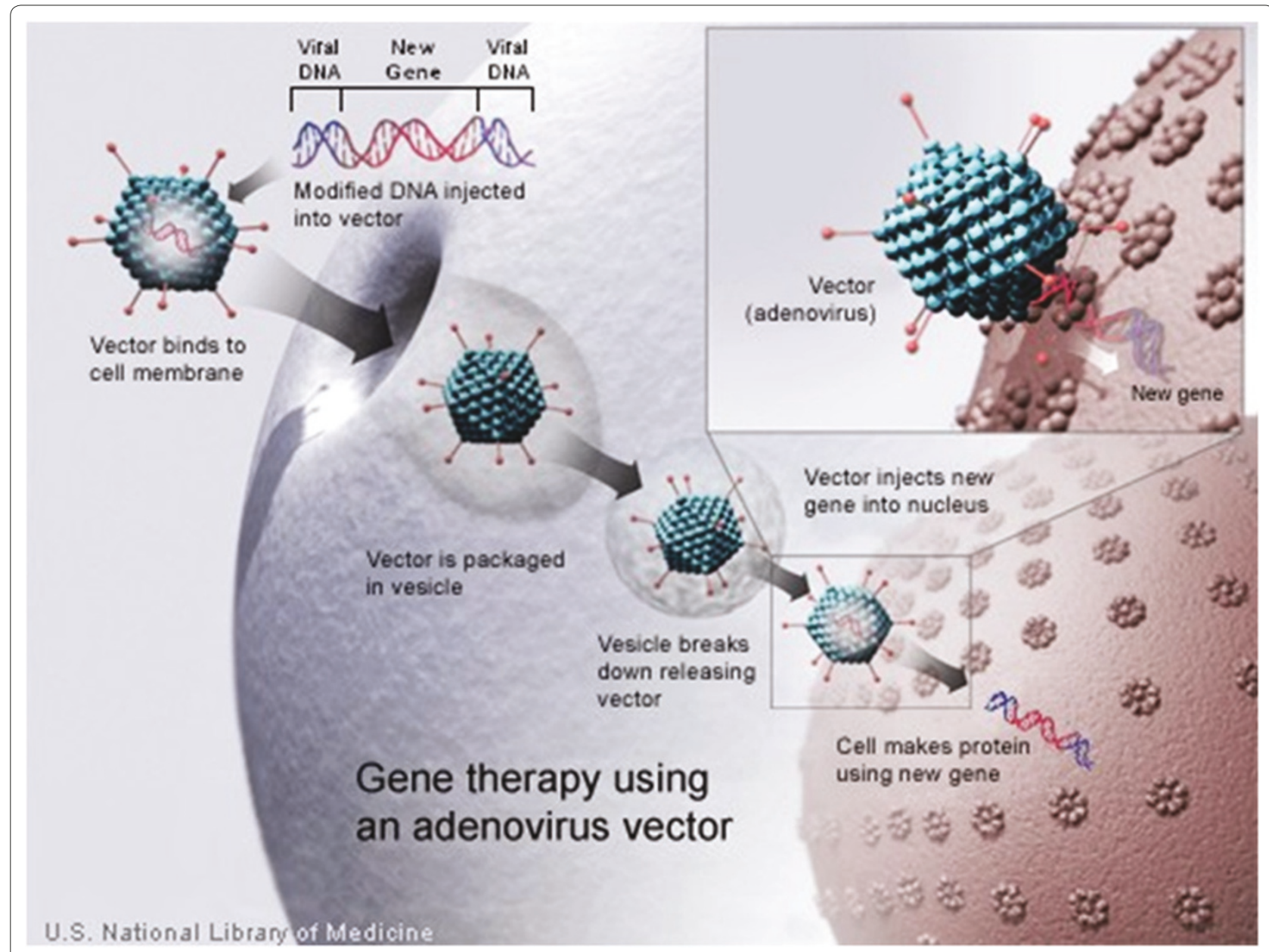

Figure 1. Schematic diagram of the mechanisms involved in viral vector-mediated gene therapy. The adenoviral vector encoding a new gene of interest binds to a cell membrane, becoming internalized within a vesicle, is subsequently released from the vesicle and is transported towards the nucleus, where it releases its genetic material, which is subsequently transcribed and translated to produce the therapeutic protein. This image is a work of the National Institutes of Health, part of the United States Department of Health and Human Services, and is in the public domain.

humans [33] and in animal models [28,34]. shRNA is a single strand of RNA that, when introduced into the cell, is reverse transcribed and integrated into the genome, becoming heritable. During subsequent transcription, the sequence generates an oligonucleotide with a tight hairpin turn that is processed into siRNA. shRNAs have reduced lung injury in animal models [35,36]. Decoy oligonucleotides are double-stranded DNA molecules of 20 to 28 nucleotides, which bind to specific transcription factors to reduce expression of targeted genes, and have been successfully used in animal models $[37,38]$.

\section{Cell-delivered gene therapy}

An alternative approach is to use systemically delivered cells to deliver genes to the lung. This approach has been used to enhance the therapeutic potential of stem cells such as mesenchymal stem/stromal cells, which demonstrate promise in preclinical ALI/ARDS models [39]. Fibroblasts have also been used to successfully deliver genes to the lung to attenuate ALI [40]. Preliminary data from a clinical trial in pulmonary hypertension show that endothelial progenitor cells overexpressing endothelial nitric oxide synthase (NOS3) decrease pulmonary vascular resistance [41], highlighting the potential of cell-delivered gene therapy for ALI/ARDS.

\section{Delivery of vector to the lung Airway delivery}

Nebulization of genetic material into the lung is effective [42], safe and well tolerated $[32,43,44]$. The integrity of AAV vectors $[9,43]$ and adenoviral virus vectors $[44]$ are maintained post nebulization, as are cationic lipid vectors [32] and DNA and RNA oligonucleotides [45]. A number of gene therapy clinical trials have utilized nebulization 
to deliver the transgene to the lung $[23,43]$, but without clear clinical benefit to date $[43,44]$.

\section{Intravascular delivery}

Intravascular delivery approaches target the lung endothelium. These approaches have been successfully used in preclinical studies of cell-based gene therapies [39,40], and also with vectors that incorporate components such as antibodies to target antigens on the lung endothelium [10].

\section{Barriers to effective gene therapy in ARDS}

Successful gene-based therapies require the delivery of high quantities of the gene or oligonucleotide to the pulmonary epithelial or endothelial surface, require efficient entry into the cytoplasm of these large and insoluble nucleic acids, which then have to move from the cytoplasm into the nucleus, and activate transcription of its product. Multiple barriers exist that hinder this process, not least the natural defense mechanisms of the lung, and additional difficulties that exist in transducing the acutely injured lung (Table 2). Limitations regarding delivery technologies and deficiencies in our knowledge regarding the optimal molecular targets also reduce the efficacy of these approaches.

\section{Pulmonary defense mechanisms}

The lung has evolved effective barriers to prevent the uptake of any inhaled foreign particles [46]. While advantageous in minimizing the potential for uptake of external genetic material (for example, viral DNA), these barriers make it more difficult to use gene-based therapies in the lung. Barriers to entry of foreign genetic material into the lung include airway mucus and the epithelial lining fluid, which traps and clears inhaled material. The glycocalyceal barrier hinders contact with the cell membrane, while the tight intercellular epithelial junctions and limited luminal endocytosis further restrict entry of foreign material into the epithelial cells.

\section{Difficulties transducing the injured lung}

Transducing the acutely injured lung may be difficult, due to the presence of pulmonary edema, consolidated or collapsed alveoli, and additional extracellular barriers such as mucus. Gene-based therapies targeted at the pulmonary epithelium may be less effective where there is extensive denudation of the pulmonary epithelium, as may occur in primary ARDS. Encouragingly, there is some evidence to suggest that ALI may not substantially impair viral gene transfer to the alveolar epithelium [47].

\section{Limitations of vector systems}

The key limitation of nonviral vector approaches has been their lack of efficiency in mediating gene transfer
Table 2. Technical challenges to gene-based therapies for ALI/ARDS models

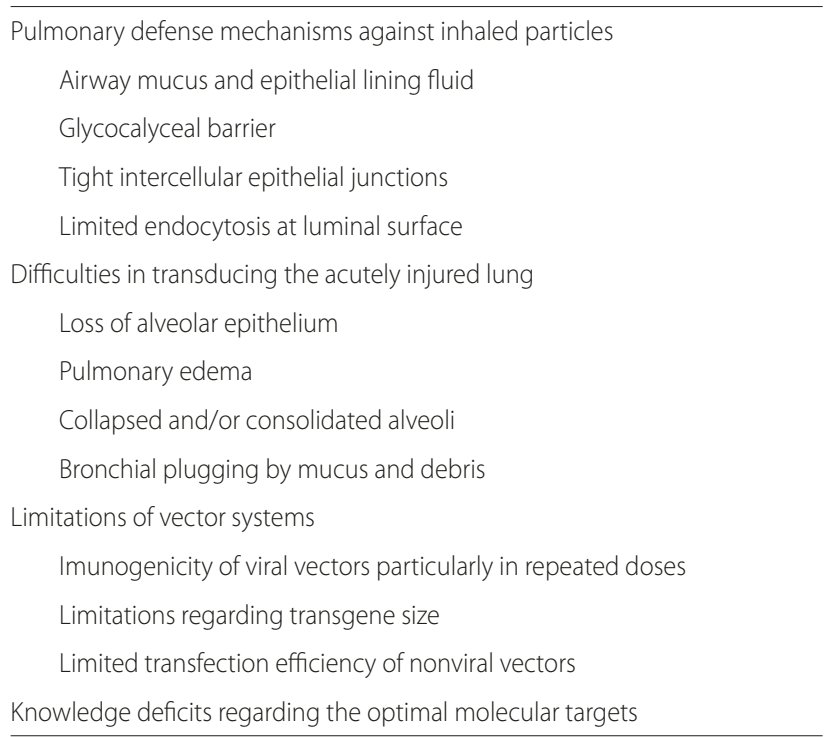

ALI, acute lung injury; ARDS, acute respiratory distress syndrome.

and transgene expression in the airway epithelium. Viral vectors are immunogenic, due to the protein coat of the viral vector, and the immune response is related to both vector dose and number of administrations. The potential to limit administration to a single dose in ALI/ARDS may reduce this risk. However, the development of an inflammatory response resulting in death following administration of a first-generation adenoviral vector highlights the risks involved [48]. Additional limitations of viral vectors include transgene size, which is limited by the size of the capsid that encloses the viral genes.

\section{Insights from preclinical ALI/ARDS studies}

The therapeutic potential of gene therapy for ALI/ARDS is underlined by a growing body of literature demonstrating efficacy in relevant preclinical models. In considering the clinical implications of these studies, it is important to acknowledge that animal models of ARDS do not fully replicate the complex pathophysiological changes seen in the clinical setting. This is highlighted by the fact that many pharmacologic strategies demonstrating considerable promise in preclinical studies were later proven ineffective in clinical trials. Nevertheless, these studies provide insights into the clinical potential of these strategies.

\section{Studies using viral vectors}

Adenovirus-mediated transfer of a gene that enhances surfactant production improves lung function and confers resistance to Pseudomonas aeruginosa infection (Figure 2) [49]. Adenovirus-delivered superoxide dismutase and catalase genes protected against hyperoxic-induced, 


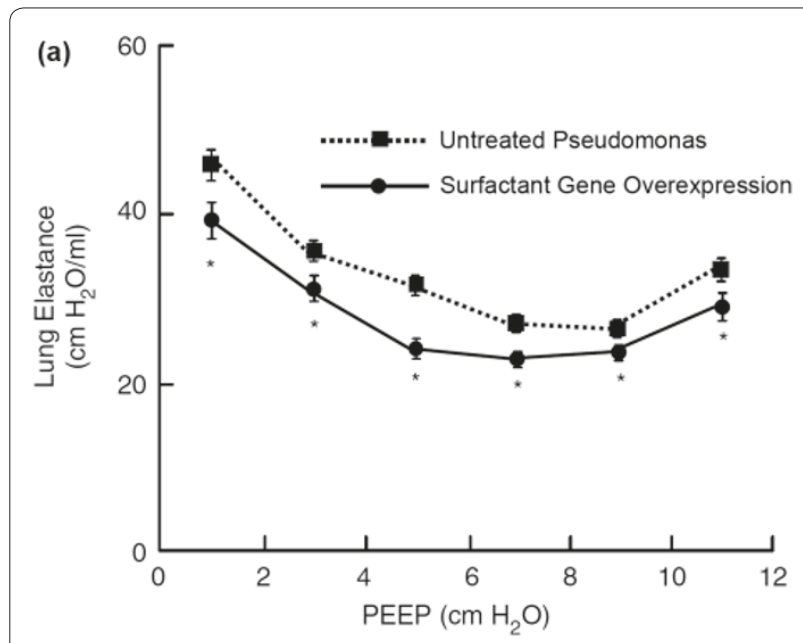

(b)

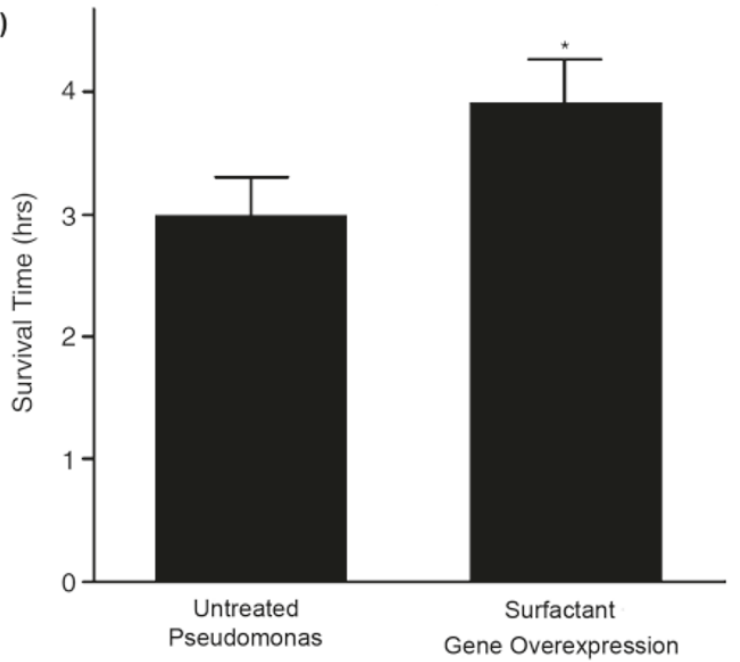

Figure 2. Adenovirus-mediated gene transfer enhances surfactant production, improves lung function and confers resistance to infection. Intratracheal delivery of adenovirus encoding a modified surfactant enzyme enhances lung production of surfactant, and (a) attenuated the decrement in lung elastance and (b) increased the survival time in mice infected with Pseudomonas aeruginosa. PEEP, positive end-expiratory pressure. Reproduced with permission from The Nature Publishing Group [49].

but not ischemia-reperfusion-induced, lung injury [50]. More recent studies have demonstrated the therapeutic potential of overexpression of a number of genes, including angiopoietin-1 [51], HSP-70 [52], apolipoprotein A-1 [53], defensin $\beta 2$ [54] and the $\mathrm{Na}^{+}, \mathrm{K}^{+}$-ATPase pump [55]. In contrast, overexpression of IL-1 $\beta$ can directly cause ALI [56], while overexpression of suppressor of cytokine signaling-3 worsens immune-complex-induced ALI [57]. Intriguingly, intratracheal administration of adenoviral vector incorporating IL-10, prior to zymosan-induced lung injury, improved survival at a lower dose but was ineffective and even harmful at higher doses [58].

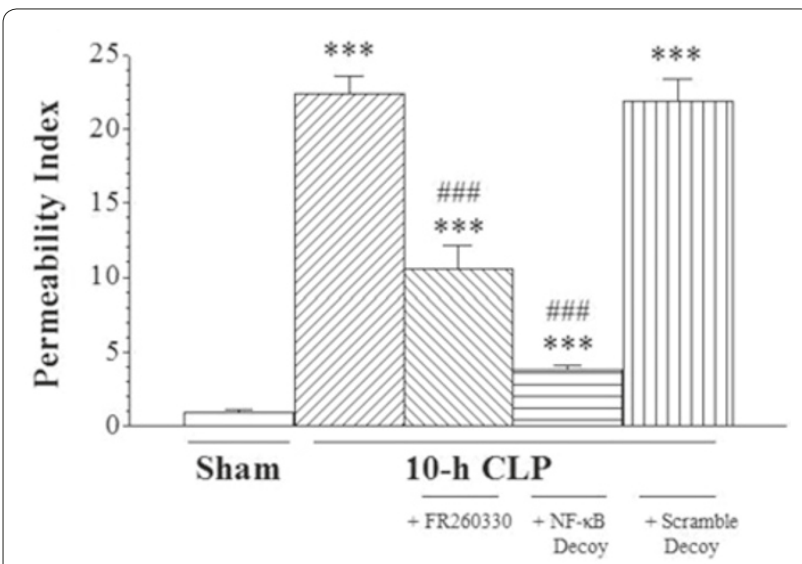

Figure 3. NF-KB decoy oligodeoxynucleotides prevent acute lung injury in mice with cecal ligation and puncture-induced sepsis. The animals were subjected to sham operation (control), sepsis (10 hours after cecal ligation and puncture (CLP)), sepsis with the NF-KB pharmacologic inhibitor FR260330, and sepsis with transfection of NF-kB decoy or its scrambled form. Transpulmonary flux of radiolabeled albumin was used to assess changes in lung permeability. ${ }^{* *} P<0.001$ compared with the sham-operated control group. \#\#\#P<0.001 compared with the CLP group without treatment. Reproduced with permission from The American Society for Pharmacology and Experimental Therapeutics [37].

\section{Studies using nonviral vectors}

An early murine study demonstrated that cationic lipidmediated transfer of the $\mathrm{Na}^{+}, \mathrm{K}^{+}$-ATPase gene ameliorated high-permeability pulmonary edema [59]. Electroporationassisted gene transfer of plasmids encoding for $\mathrm{Na}^{+}, \mathrm{K}^{+}-$ ATPase reverses endotoxin-induced lung injury [60]. The lipoplex-delivered IL-10 gene decreased lung and systemic organ injury induced by cecal ligation and puncture in mice [61]. Systemically administered cationic polyethylenimine polyplexes incorporating indoleamine2,3-dioxygenase transduced pulmonary endothelial cells and decreased lung ischemia-reperfusion injury [62].

\section{Studies using DNA and RNA oligonucleotides}

NF- $\kappa B$ decoy oligonucleotides, incorporated into viral vectors, attenuate systemic sepsis-induced lung injury when administered intravenously (Figure 3) [37]. In animal models, both intratracheal $[34,63]$ and intravenously $[29,64]$ administered siRNA successfully silence their target genes. shRNA-based approaches have been used to suppress silica-induced lung fibrosis [35] and to ameliorate lung ischemia-reperfusion-induced lung injury [36]. More recently, aerosolization of siRNA that targets respiratory syncytial virus viral replication was safe and potentially effective in patients post lung transplant with respiratory syncytial virus infection [33], clearly illustrating the therapeutic potential of these approaches for ALI/ARDS. 


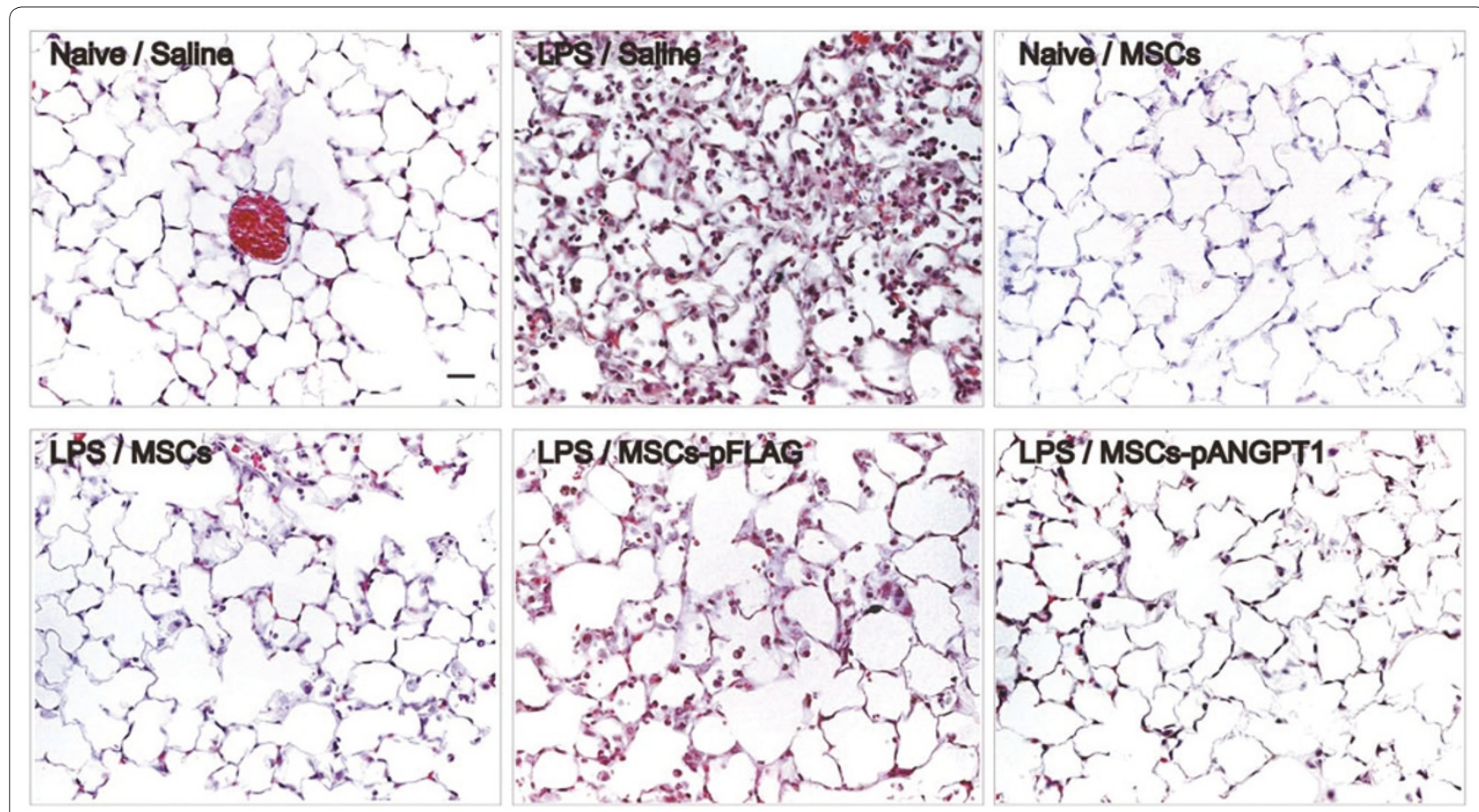

Figure 4. Gene-based therapies may be combined with stem cells to enhance their effect. Representative histologic images of lung sections demonstrate that modification of mesenchymal stem/stromal cells (MSCs) to overexpress angiopoeitin-1 (LPS/MSCs-pANGPT1) enhanced its efficacy in attenuating endotoxin-induced lung injury (LPS/Saline) compared with MSCs alone (LPS/MSCs) or MSCs overexpressing a nonfunctional gene (LPS/MSCs-pFLAG). Reproduced with permission from The Public Library of Science [39].

\section{Studies using cell-delivered gene therapy}

Mei and colleagues enhanced the efficacy of mesenchymal stem/stromal cells in endotoxin-induced ALI by transducing them to overexpress angiopoeitin-1 (Figure 4) [39]. Mesenchymal stem/stromal cells overexpressing IL-10 decreased alveolar infiltration of CD4 and CD8 $\mathrm{T}$ cells following lung ischemia-reperfusion injury [65]. Bone marrow stem cells expressing keratinocyte growth factor attenuate bleomycin-induced lung injury [66]. Nonstem cells can also be used to deliver genes to the injured lung [67]. Fibroblasts overexpressing angiopoeitin-1 attenuate endotoxin-induced lung injury [40], while fibroblasts overexpressing vascular endothelial growth factor and endothelial nitric oxide synthase can attenuate or even reverse endotoxin-induced ALI [68].

\section{Gene-based therapies for ALI/ARDS: future directions}

Advances in the identification of therapeutic targets, improvements in viral and nonviral vector technologies, and regulation of gene-based therapies by temporal and spatial targeting offer the potential to translate the therapeutic promise of gene-based therapies for ALI/ ARDS to the clinical setting (Table 3).

\section{Better viral vectors}

Viral vectors remain the focus of intensive research to optimize their efficiency, to minimize their immunogenicity and to enhance their tissue specificity $[19,31,69,70]$. Strategies to develop less immunogenic vectors have focused on modifying the naturally occurring proteins in the viral coat [71]. Much research has been devoted to searching and characterizing both naturally occurring [71] and engineered capsid variants from mammalian species [72]. Capsid protein modification has also been used to enhance tissue specificity [70]. Envelope protein pseudotyping involves encapsulating the modified genome from one virus, such as simian immunodeficiency virus, with envelope proteins from another virus, such as vesicular stomatitic virus. This encapsulation can enhance the therapeutic potential of viral vectors, by combining the advantages of one viral genome (for example, bigger payload or site-specific integration) with the tissue tropism of another virus.

\section{Better nonviral vectors}

Strategies to enhance the effectiveness of the lipoplexes used to deliver plasmids and other DNA/RNA oligonucleotides involve manipulation of the lipoplex lipid content and the use of targeting peptides. The choice of lipid influences expression efficiency by enhancing release of the genetic material within the target cell $[73,74]$. Targeting peptides increases transfection efficiency by directing the lipid to a particular cell membrane or cell type [31]. Physical methods of plasmid delivery 


\section{Table 3. Future directions for gene-based therapies}

Viral vectors

Capsid protein modification to reduce immunogenicity [71]

Capsid protein modification to enhance tissue specificity [70]

Envelope protein pseudotyping

Nonviral vectors

Manipulation of lipoplex lipid content to enhance cellular uptake $[73,74]$

Use of targeting peptides on lipoplexes and polyplexes [31]

Strategies to enhance gene transfer; for example, electroporation, ultrasound, gene gun delivery

Gene expression strategies

Modifying transgene DNA to eliminate bacterial motifs [75,76]

Development of high-efficiency tissue-specific promoters [77-80]

Development of promoters that regulate gene expression [83]

Enhanced therapeutic targeting

Nebulization technologies [9]

Strategies to target the pulmonary endothelium [10]

Improved cellular uptake of vector

Surface active agents to enhance vector spread [84]

Reduce ubiquitination of viral capsid proteins [85]

Better therapeutic targets

Enhancement or restoration of lung epithelial and/or endothelial cell function [86]

Strengthening lung defense mechanisms against injury [87]

Speeding clearance of inflammation and infection

Enhancement of the repair process following ALI/ARDS [88].

ALI, acute lung injury; ARDS, acute respiratory distress syndrome.

such as electroporation [60] and ultrasound can enhance gene transfer by bringing the plasmid DNA into closer proximity with the cell membrane and/or causing temporary disruption of the cell membrane. Other physical methods can also be used to increase in vivo gene transfer, including pressurized vascular delivery, laser, magnetic fields and gene gun delivery. These systems enable plasmid-based gene delivery to reach efficiencies close to that achieved with viral vectors.

\section{Enhanced gene expression strategies}

Successful gene therapy relies upon being able to target the injury site, and to control the duration and levels of gene expression. Modifying the transgene DNA to exclude nonmethylated CpG motifs, typical of bacterial DNA, decreases the immune response and may increase transgene expression [75,76]. High-efficiency tissue-specific promoters may improve the efficiency and specificity of transgene expression. Lung-specific promoters include surfactant promoters [77] such as the surfactant protein C promoter [78], a ciliated cell-specific promoter FOXJ1 [79], the cytokeratin 18 promoter [80], and the Clara cell 10-kDa protein [78]. Promoters can also be used to target a specific phase of illness, switching on when required to produce an effect at the optimal time point.

A related approach is the development of promoters that allow for transfected genes to be turned on and off. Currently, the tetracycline-dependent gene expression vector [81] is the most widely used regulated system as it has a good safety profile. Tetracycline is rapidly metabolized and cleared from the body, making it an ideal drug to control gene expression. However, the potential for an activator such as tetracycline to modulate the lung injury should be borne in mind. New-generation transactivators, with no basal activity and increased sensitivity, have now been developed [82]. In an ARDS context, conditional regulation of gene expression by the combined use of a lung-specific promoter and the tetracycline-dependent gene expression system may be a useful approach [83]. (a)

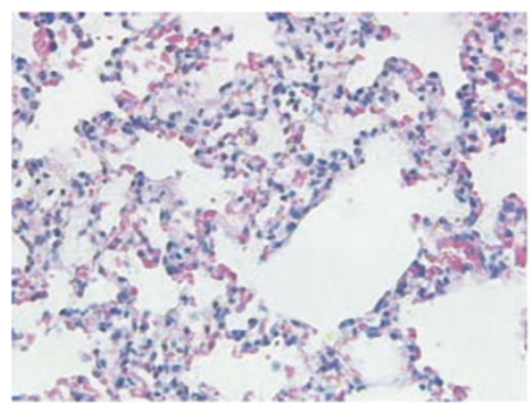

(b)

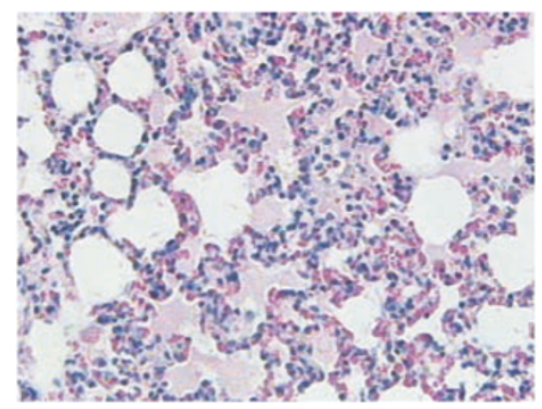

(c)

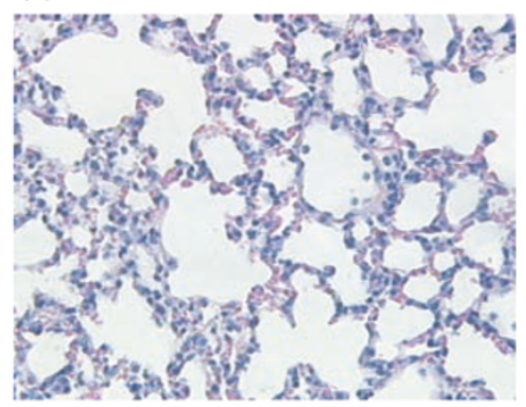

Figure 5. Therapeutic potential of selectively targeting the pulmonary endothelium with systemically delivered gene-based therapies. The antioxidant enzyme catalase was conjugated with antibodies to the adhesion molecule PECAM. The anti-PECAM/catalase conjugate, but not a nonspecific lgG/catalase conjugate, bound specifically to the pulmonary endothelium, and attenuated hydrogen peroxide $\left(\mathrm{H}_{2} \mathrm{O}_{2}\right)$ injury. (a) $\mathrm{H}_{2} \mathrm{O}_{2}$ produces a severe lung injury, (b) which is not attenuated by the nonspecific lgG/catalase conjugate. (c) In contrast, the anti-PECAM/catalase conjugate does attenuate lung injury. Reproduced with permission from the American Physiological Society [10]. 
Table 4. Key points regarding gene-based therapies for ALI/ARDS

ALI/ARDS may be amenable to gene-based therapies

Ongoing advances in our understanding of the pathophysiology of ALI/ARDS have revealed multiple therapeutic targets for gene-based approaches

Numerous gene-based approaches have demonstrated promise in relevant preclinical models

The clinical potential for gene-based approaches to ALI/ARDS remains to be realized

Multiple barriers exist to successful gene-based approaches for ALI/ARDS

A greater understanding of the molecular mechanisms underlying injury and repair in ALI/ARDS, coupled with improvements in gene-based approaches, offer hope for ALI/ARDS

ALI, acute lung injury; ARDS, acute respiratory distress syndrome.

\section{Enhanced therapeutic targeting}

An advantage of gene-based strategies is the ability to target specific cells within an organ; for example, the epithelial cells of the lung. Novel nebulization technologies, which facilitate the delivery of large quantities of undamaged vector to the distal lung, demonstrate considerable promise in this regard [9]. Alternative approaches to spatial targeting include targeting specific receptors that are plentiful on the target cell to increase transfection efficiency. An interesting development in this regard is the targeting of systemically administered therapies to the pulmonary endothelium using antibodies to proteins expressed preferentially on these cells (Figure 5) [10]. In these studies, the antioxidant enzyme catalase was conjugated with antibodies to the adhesion molecule PECAM, which is widely expressed on pulmonary endothelial cells, and to a nonspecific IgG antibody. The anti-PECAM/catalase conjugate, but not the IgG/catalase conjugate, bound specifically to the pulmonary endothelium and attenuated hydrogen peroxide injury.

\section{Improved cellular uptake of vector}

Specific strategies have been developed to maximize uptake of vector into alveolar epithelial cells. It is possible to enhance lung transgene expression with the use of surface-active agents such as perflurocarbon, which enhances the spread of vector and mixing within the epithelial lining fluid [84]. Agents that reduce ubiquitination of AAV capsid proteins following endocytosis, such as tripeptide proteasome inhibitors, dramatically augment $(>2,000$-fold) AAV vector transduction in airway epithelia [85].

\section{Better therapeutic targets}

Ultimately, the success or failure of gene-based therapies for ALI/ARDS is likely to rest on the identification of better gene targets. Ongoing advances in our understanding of the pathophysiology of ALI/ARDS continue to reveal novel therapeutic targets for gene-based approaches. Promising potential approaches include strategies to enhance or restore lung epithelial and/or endothelial cell function [86], to strengthen lung defense mechanisms against injury [87], to speed clearance of inflammation and infection, and to enhance the repair process following ALI/ARDS [88].

\section{Summary and conclusions}

ALI/ARDS may be a particularly suitable disease process for gene-based therapies (Table 4). This is supported by increasing evidence from relevant preclinical ARDS models for the efficacy of gene-based therapies that enhance or restore lung epithelial and/or endothelial cell function, strengthen lung defense mechanisms against injury, speed resolution of inflammation and infection, and enhance the repair process following ALI/ARDS. Despite this promising preclinical evidence, the potential for gene based approaches to ALI/ARDS in the clinical setting remains to be realized. Multiple barriers exist to the successful use of gene-based therapies in the lung, which limit the efficacy of these approaches. Future research approaches should focus on overcoming these barriers, by developing more effective and less immunogenic vector delivery systems, developing strategies to focus gene expression on specific injury zones of the lung for defined time periods, and identifying better molecular targets that can take advantage of these potentially very powerful therapeutic approaches.

\section{Abbreviations}

AAV, adeno-associated virus; ALI, acute lung injury; ARDS, acute respiratory distress syndrome; IL, interleukin; NF, nuclear factor; shRNA, small hairpin RNA; siRNA, small interfering RNA.

\section{Competing interests}

The authors declare that they have no competing interests.

\section{Acknowledgements}

The present work was supported by funding from the Health Research Board, Dublin, Ireland (Grant No. RP/2008/193), and by the European Research Council, Brussels, Belgium, under the Framework 7 Programme (Grant No. ERC-2007-StG 207777).

\section{Author details}

'Lung Biology Group, Regenerative Medicine Institute, National Centre for Biomedical Engineering Science, Orbsen Building, National University of Ireland, Newcastle Road, Galway, Ireland. 2Department of Anaesthesia and Intensive Care Medicine, Galway University Hospitals, Newcastle Road, Galway, Ireland. ${ }^{3}$ Anaesthesia, School of Medicine, Clinical Sciences Institute, National University of Ireland Galway, Newcastle Road, Galway, Ireland.

Published: 20 June 2011 


\section{References}

1. Rubenfeld GD: Epidemiology of acute lung injury. Crit Care Med 2003, 31(4 Suppl):S276-S284

2. Rubenfeld G, Caldwell E, Peabody E, Weaver J, Martin D, Neff M, Stern E, Hudson L: Incidence and outcomes of acute lung injury. N Eng/ J Med 2005, 353:1685-1693.

3. Herridge MS, Cheung AM, Tansey CM, Matte-Martyn A, Diaz-Granados N, Al-Saidi F, Cooper AB, Guest CB, Mazer CD, Mehta S, Stewart TE, Barr A, Cook $D$, Slutsky AS: One-year outcomes in survivors of the acute respiratory distress syndrome. N Engl J Med 2003, 348:683-693.

4. Ventilation with lower tidal volumes as compared with traditional tidal volumes for acute lung injury and the acute respiratory distress syndrome. The Acute Respiratory Distress Syndrome Network. N Engl J Med 2000, 342:1301-1308.

5. Wheeler A, Bernard G, Thompson B, Schoenfeld D, Wiedemann H, deBoisblanc B, Connors AJ, Hite R, Harabin A: Pulmonary-artery versus central venous catheter to guide treatment of acute lung injury. $N$ Engl J Med 2006, 354:2213-2224.

6. Sud S, Friedrich JO, Taccone P, Polli F, Adhikari NK, Latini R, Pesenti A, Guerin C, Mancebo J, Curley MA, Fernandez R, Chan MC, Beuret P, Voggenreiter G, Sud $M$, Tognoni $G$, Gattinoni L: Prone ventilation reduces mortality in patients with acute respiratory failure and severe hypoxemia: systematic review and meta-analysis. Intensive Care Med 2010, 36:585-599.

7. Peek GJ, Mugford M, Tiruvoipati R, Wilson A, Allen E, Thalanany MM, Hibbert CL, Truesdale A, Clemens F, Cooper N, Firmin RK, Elbourne D: Efficacy and economic assessment of conventional ventilatory support versus extracorporeal membrane oxygenation for severe adult respiratory failure (CESAR): a multicentre randomised controlled trial. Lancet 2009, 374:1351-1363.

8. Ware LB, Matthay MA: The acute respiratory distress syndrome. N Eng/ J Med 2000, 342:1334-1349.

9. MacLoughlin R, Higgins B, Laffey J, O'Brien T: Optimized aerosol delivery to a mechanically ventilated rodent. J Aerosol Med Pulm Drug Deliv 2009, 22:323-332

10. Christofidou-Solomidou M, Scherpereel A, Wiewrodt R, Ng K, Sweitzer T, Arguiri E, Shuvaev V, Solomides CC, Albelda SM, Muzykantov VR: PECAMdirected delivery of catalase to endothelium protects against pulmonary vascular oxidative stress. Am J Physiol Lung Cell Mol Physiol 2003 , 285:L283-L292.

11. Simpson A, Wallace W, Marsden M, Govan J, Porteous D, Haslett C, Sallenave J: Adenoviral augmentation of elafin protects the lung against acute injury mediated by activated neutrophils and bacterial infection. J Immuno/ 2001, 167:1778-1786.

12. Katkin J, Gilbert B, Langston C, French K, Beaudet A: Aerosol delivery of a $\beta$-galactosidase adenoviral vector to the lungs of rodents. Human Gene Ther 1995, 6:985-995.

13. Scaria A, St George J, Jiang C, Kaplan J, Wadsworth S, Gregory R: Adenovirusmediated persistent cystic fibrosis transmembrane conductance regulator expression in mouse airway epithelium. J Virol 1998, 72:7302-7309.

14. Harvey BG, Leopold PL, Hackett NR, Grasso TM, Williams PM, Tucker AL, Kaner RJ, Ferris B, Gonda I, Sweeney TD, Ramalingam R, Kovesdi I, Shak S, Crystal RG: Airway epithelial CFTR mRNA expression in cystic fibrosis patients after repetitive administration of a recombinant adenovirus. J Clin Invest 1999, 104:1245-1255

15. Crystal RG, Harvey BG, Wisnivesky JP, O'Donoghue KA, Chu KW, Maroni J, Muscat JC, Pippo AL, Wright CE, Kaner RJ, Leopold PL, Kessler PD, Rasmussen HS, Rosengart TK, Hollmann C: Analysis of risk factors for local delivery of low- and intermediate-dose adenovirus gene transfer vectors to individuals with a spectrum of comorbid conditions. Human Gene Ther 2002, 13:65-100

16. Hay J, McElvaney N, Herena J, Crystal R: Modification of nasal epithelial potential differences of individuals with cystic fibrosis consequent to local administration of a normal CFTR CDNA adenovirus gene transfer vector. Human Gene Ther 1995, 6:1487-1496.

17. Zuckerman JB, Robinson CB, McCoy KS, Shell R, Sferra TJ, Chirmule N, Magosin SA, Propert KJ, Brown-Parr EC, Hughes JV, Tazelaar J, Baker C, Goldman MJ, Wilson JM: A phase I study of adenovirus-mediated transfer of the human cystic fibrosis transmembrane conductance regulator gene to a lung segment of individuals with cystic fibrosis. Human Gene Ther 1999, 10:2973-2985

18. Joseph PM, O'Sullivan BP, Lapey A, Dorkin H, Oren J, Balfour R, Perricone MA,
Rosenberg M, Wadsworth SC, Smith AE, St George JA, Meeker DP: Aerosol and lobar administration of a recombinant adenovirus to individuals with cystic fibrosis. I. Methods, safety, and clinical implications. Human Gene Ther 2001, 12:1369-1382.

19. Büning H, Perabo L, Coutelle O, Quadt-Humme S, Hallek M: Recent developments in adeno-associated virus vector technology. J Gene Med 2008, 10:717-733.

20. Liu X, Luo M, Guo C, Yan Z, Wang Y, Lei-Butters D, Engelhardt J: Analysis of adeno-associated virus progenitor cell transduction in mouse lung. Mol Ther 2009, 17:285-293.

21. Zabner J, Seiler M, Walters R, Kotin RM, Fulgeras W, Davidson BL, Chiorini JA: Adeno-associated virus type 5 (AAV5) but not AAV2 binds to the apical surfaces of airway epithelia and facilitates gene transfer. J Virol 2000, 74:3852-3858.

22. Halbert CL, Allen JM, Miller AD: Adeno-associated virus type 6 (AAV6) vectors mediate efficient transduction of airway epithelial cells in mouse lungs compared to that of AAV2 vectors. J Virol 2001, 75:6615-6624.

23. Moss RB, Rodman D, Spencer LT, Aitken ML, Zeitlin PL, Waltz D, Milla C, Brody AS, Clancy JP, Ramsey B, Hamblett N, Heald AE: Repeated adeno-associated virus serotype 2 aerosol-mediated cystic fibrosis transmembrane regulator gene transfer to the lungs of patients with cystic fibrosis: a multicenter, double-blind, placebo-controlled trial. Chest 2004 125:509-521.

24. Wagner JA, Messner AH, Moran ML, Daifuku R, Kouyama K, Desch JK, Manley S, Norbash AM, Conrad CK, Friborg S, Reynolds T, Guggino WB, Moss RB, Carter BJ, Wine JJ, Flotte TR, Gardner P: Safety and biological efficacy of an adeno-associated virus vector-cystic fibrosis transmembrane regulator (AAV-CFTR) in the cystic fibrosis maxillary sinus. Laryngoscope 1999, 109(2 Pt 1):266-274.

25. Sinn P, Hickey M, Staber P, Dylla D, Jeffers S, Davidson B, Sanders D, McCray P. Lentivirus vectors pseudotyped with filoviral envelope glycoproteins transduce airway epithelia from the apical surface independently of folate receptor alpha. J Virol 2003, 77:5902-5910.

26. Cavazzana-Calvo M, Hacein-Bey S, de Saint Basile G, Gross F, Yvon E, Nusbaum P, Selz F, Hue C, Certain S, Casanova JL, Bousso P, Deist FL, Fischer A: Gene therapy of human severe combined immunodeficiency (SCID)-X1 disease. Science 2000, 288:669-672.

27. Hacein-Bey-Abina S, Garrigue A, Wang GP, Soulier J, Lim A, Morillon E, Clappier E, Caccavelli L, Delabesse E, Beldjord K, Asnafi V, Maclntyre E, Dal Cortivo L, Radford I, Brousse N, Sigaux F, Moshous D, Hauer J, Borkhardt A, Belohradsky BH, Wintergerst U, Velez MC, Leiva L, Sorensen R, Wulffraat N, Blanche S, Bushman FD, Fischer A, Cavazzana-Calvo M: Insertional oncogenesis in 4 patients after retrovirus-mediated gene therapy of SCIDX1. J Clin Invest 2008, 118:3132-3142.

28. $\mathrm{LiT}$, Folkesson $\mathrm{H}$ : RNA interference for $\mathrm{a}-\mathrm{ENaC}$ inhibits rat lung fluid absorption in vivo. Am J Physiol Lung Cell Mol Physiol 2006, 290:L649-L660.

29. Saitoh H, Masuda T, Zhang X, Shimura S, Shirato K: Effect of antisense oligonucleotides to nuclear factor-KB on the survival of LPS-induced ARDS in mouse. Exp Lung Res 2002, 28:219-231.

30. Zhou R, Norton J, Zhang N, Dean D: Electroporation-mediated transfer of plasmids to the lung results in reduced TLR9 signaling and inflammation. Gene Ther 2007, 14:775-780.

31. Tagalakis AD, McAnulty RJ, Devaney J, Bottoms SE, Wong JB, Elbs M, Writer MJ, Hailes HC, Tabor AB, O'Callaghan C, Jaffe A, Hart SL: A receptor-targeted nanocomplex vector system optimized for respiratory gene transfer. $\mathrm{Mol}$ Ther 2008, 16:907-915.

32. Alton EW, Stern M, Farley R, Jaffe A, Chadwick SL, Phillips J, Davies J, Smith SN, Browning J, Davies MG, Hodson ME, Durham SR, Li D, Jeffery PK, Scallan M, Balfour R, Eastman SJ, Cheng SH, Smith AE, Meeker D, Geddes DM: Cationic lipid-mediated CFTR gene transfer to the lungs and nose of patients with cystic fibrosis: a double-blind placebo-controlled trial. Lancet 1999, 353:947-954.

33. Zamora MR, Budev M, Rolfe M, Gottlieb J, Humar A, Devincenzo J, Vaishnaw A, Cehelsky J, Albert G, Nochur S, Gollob JA, Glanville AR: RNA interference therapy in lung transplant patients infected with respiratory syncytial virus. Am J Respir Crit Care Med 2011, 183:531-538.

34. Lomas-Neira J, Chung C, Wesche D, Perl M, Ayala A: In vivo gene silencing (with siRNA) of pulmonary expression of MIP- 2 versus $K C$ results in divergent effects on hemorrhage-induced, neutrophil-mediated septic acute lung injury. $J$ Leukoc Biol 2005, 77:846-853.

35. Wang $X$, Chen $Y, L v L$, Chen J: Silencing CD36 gene expression results in the 
inhibition of latent-TGF- $\beta 1$ activation and suppression of silica-induced lung fibrosis in the rat. Respir Res 2009, 10:36.

36. Zhang YX, Fan H, Shi Y, Xu ST, Yuan YF, Zheng RH, Wang Q: Prevention of lung ischemia-reperfusion injury by short hairpin RNA-mediated caspase-3 gene silencing. J Thorac Cardiovasc Surg 2010, 139:758-764.

37. Matsuda N, Hattori Y, Jesmin S, Gando S: Nuclear factor-kB decoy oligodeoxynucleotides prevent acute lung injury in mice with cecal ligation and puncture-induced sepsis. Mol Pharmacol 2005, 67:1018-1025.

38. Li Y, He B, Wang Y, Wang J: Effects of intratracheal administration of nuclear factor-kB decoy oligodeoxynucleotides on long-term cigarette smokeinduced lung inflammation and pathology in mice. Respir Res 2009, 10:79.

39. Mei S, McCarter S, Deng Y, Parker C, Liles W, Stewart D: Prevention of LPSinduced acute lung injury in mice by mesenchymal stem cells overexpressing angiopoietin 1. PLoS Med 2007, 4:e269

40. McCarter SD, Mei SH, Lai PF, Zhang QW, Parker CH, Suen RS, Hood RD, Zhao YD, Deng Y, Han RN, Dumont DJ, Stewart DJ: Cell-based angiopoietin-1 gene therapy for acute lung injury. Am J Respir Crit Care Med 2007, 175:1014-1026.

41. Weiss D, Kolls J, Ortiz L, Panoskaltsis-Mortari A, Prockop D: Stem cells and cell therapies in lung biology and lung diseases. Proc Am Thorac Soc 2008, 5:637-667.

42. Leung K, Louca E, Munson K, Dutzar B, Anklesaria P, Coates A: Calculating expected lung deposition of aerosolized administration of AAV vector in human clinical studies. J Gene Med 2007, 9:10-21

43. Moss RB, Milla C, Colombo J, Accurso F, Zeitlin PL, Clancy JP, Spencer LT, Pilewski J, Waltz DA, Dorkin HL, Ferkol T, Pian M, Ramsey B, Carter BJ, Martin DB, Heald AE: Repeated aerosolized AAV-CFTR for treatment of cystic fibrosis: a randomized placebo-controlled phase $2 B$ trial. Human Gene Ther 2007, 18:726-732.

44. Perricone MA, Morris JE, Pavelka K, Plog MS, O'Sullivan BP, Joseph PM, Dorkin H, Lapey A, Balfour R, Meeker DP, Smith AE, Wadsworth SC, St George JA: Aerosol and lobar administration of a recombinant adenovirus to individuals with cystic fibrosis. II. Transfection efficiency in airway epithelium. Human Gene Ther 2001, 12:1383-1394.

45. Garbuzenko O, Saad M, Pozharov V, Reuhl K, Mainelis G, Minko T: Inhibition of lung tumor growth by complex pulmonary delivery of drugs with oligonucleotides as suppressors of cellular resistance. Proc Natl Acad Sci USA 2010, 107:10737-10742.

46. Griesenbach U, Alton E, Consortium UCFGT: Gene transfer to the lung: lessons learned from more than 2 decades of CF gene therapy. Advanced Drug Deliv Rev 2009, 61:128-139.

47. Dumasius V, Mendez M, Mutlu G, Factor P: Acute lung injury does not impair adenoviral-mediated gene transfer to the alveolar epithelium. Chest 2002, 121(3 Suppl):33S-34S

48. Raper S, Chirmule N, Lee F, Wivel N, Bagg A, Gao G, Wilson J, Batshaw M: Fatal systemic inflammatory response syndrome in a ornithine transcarbamylase deficient patient following adenoviral gene transfer. Mol Genet Metab 2003, 80:148-158.

49. Zhou J, Wu Y, Henderson F, McCoy D, Salome R, McGowan S, Mallampalli R: Adenoviral gene transfer of a mutant surfactant enzyme ameliorates pseudomonas-induced lung injury. Gene Ther 2006, 13:974-985.

50. Danel C, Erzurum S, Prayssac P, Eissa N, Crystal R, Hervé P, Baudet B, Mazmanian M, Lemarchand P: Gene therapy for oxidant injury-related diseases: adenovirus-mediated transfer of superoxide dismutase and catalase CDNAs protects against hyperoxia but not against ischemiareperfusion lung injury. Human Gene Ther 1998, 9:1487-1496.

51. Huang Y, Sauthoff H, Herscovici P, Pipiya T, Cheng J, Heitner S, Szentirmai O, Carter B, Hay J: Angiopoietin-1 increases survival and reduces the development of lung edema induced by endotoxin administration in a murine model of acute lung injury. Crit Care Med 2008, 36:262-267.

52. Bromberg Z, Raj N, Goloubinoff P, Deutschman C, Weiss Y: Enhanced expression of 70-kilodalton heat shock protein limits cell division in a sepsis-induced model of acute respiratory distress syndrome. Crit Care Med 2008, 36:246-255

53. LiY, Dong J, Wu M: Human ApoA-I overexpression diminishes LPS-induced systemic inflammation and multiple organ damage in mice. Eur Pharmacol 2008, 590:417-422

54. Shu Q, Shi Z, Zhao Z, Chen Z, Yao H, Chen Q, Hoeft A, Stuber F, Fang X: Protection against $P$ seudomonas aeruginosa pneumonia and sepsisinduced lung injury by overexpression of $\beta$-defensin- 2 in rats. Shock 2006 , 26:365-371.
55. Adir Y, Welch L, Dumasius V, Factor P, Sznajder J, Ridge K: Overexpression of the Na-K-ATPase a2-subunit improves lung liquid clearance during ventilation-induced lung injury. Am J Physiol Lung Cell Mol Physiol 2008, 294:L1233-L1237.

56. Ganter MT, Roux J, Miyazawa B, Howard M, Frank JA, Su G, Sheppard D, Violette SM, Weinreb PH, Horan GS, Matthay MA, Pittet JF: Interleukin-1 $\beta$ causes acute lung injury via av $\beta 5$ and av $\beta 6$ integrin-dependent mechanisms. Circ Res 2008, 102:804-812.

57. Gao H, Hoesel L, Guo R, Rancilio N, Sarma J, Ward P: Adenoviral-mediated overexpression of SOCS3 enhances IgG immune complex-induced acute lung injury. J Immuno/ 2006, 177:612-620.

58. McAuliffe P, Murday M, Efron P, Scumpia P, Ungaro R, Abouhamze A, Tannahill C, Hutchins B, LaFace D, Moldawer L: Dose-dependent improvements in outcome with adenoviral expression of interleukin-10 in a murine model of multisystem organ failure. Gene Ther 2006, 13:276-282.

59. Stern M, Ulrich K, Robinson C, Copeland J, Griesenbach U, Masse C, Cheng S, Munkonge F, Geddes D, Berthiaume Y, Alton E: Pretreatment with cationic lipid-mediated transfer of the $\mathrm{Na}^{+} \mathrm{K}^{+}$-ATPase pump in a mouse model in vivo augments resolution of high permeability pulmonary oedema. Gene Ther 2000, 7:960-966

60. Mutlu G, Machado-Aranda D, Norton J, Bellmeyer A, Urich D, Zhou R, Dean D: Electroporation-mediated gene transfer of the $\mathrm{Na}^{+}, \mathrm{K}^{+}-\mathrm{ATPase}$ rescues endotoxin-induced lung injury. Am J Respir Crit Care Med 2007, 176:582-590

61. Kabay B, Kocaefe C, Baykal A, Ozden H, Baycu C, Oner Z, Ozgüç M, Sayek I: Interleukin-10 gene transfer: prevention of multiple organ injury in a murine cecal ligation and puncture model of sepsis. World J Surg 2007 31:105-115.

62. Liu H, Liu L, Visner G: Nonviral gene delivery with indoleamine 2,3-dioxygenase targeting pulmonary endothelium protects against ischemia-reperfusion injury. Am J Transplant 2007, 7:2291-2300.

63. Perl M, Chung C, Lomas-Neira J, Rachel T, Biffl W, Cioffi W, Ayala A: Silencing of Fas, but not caspase-8, in lung epithelial cells ameliorates pulmonary apoptosis, inflammation, and neutrophil influx after hemorrhagic shock and sepsis. Am J Pathol 2005, 167:1545-1559.

64. Gao C, Li R, Huan J, Li W: Caveolin-1 siRNA increases the pulmonary microvascular and alveolar epithelial permeability in rats. J Trauma 2011 70:210-219.

65. Manning E, Pham S, Li S, Vazquez-Padron R, Mathew J, Ruiz P, Salgar S: Interleukin-10 delivery via mesenchymal stem cells: a novel gene therapy approach to prevent lung ischemia-reperfusion injury. Human Gene Ther 2010, 21:713-727.

66. Aguilar S, Scotton C, McNulty K, Nye E, Stamp G, Laurent G, Bonnet D, Janes S: Bone marrow stem cells expressing keratinocyte growth factor via an inducible lentivirus protects against bleomycin-induced pulmonary fibrosis. PLoS One 2009, 4:e8013

67. Campbell A, Zhao Y, Sandhu R, Stewart D: Cell-based gene transfer of vascular endothelial growth factor attenuates monocrotaline-induced pulmonary hypertension. Circulation 2001, 104:2242-2248.

68. Zhao Y, Courtman D, Ng D, Robb M, Deng Y, Trogadis J, Han R, Stewart D: Microvascular regeneration in established pulmonary hypertension by angiogenic gene transfer. Am J Respir Cell Mol Biol 2006, 35:182-189.

69. Chtarto A, Bender HU, Hanemann CO, Kemp T, Lehtonen E, Levivier M, Brotchi $J$, Velu T, Tenenbaum L: Tetracycline-inducible transgene expression mediated by a single AAV vector. Gene Ther 2003, 10:84-94.

70. Meng Q, Robinson D, Jenkins R, McAnulty R, Hart S: Efficient transfection of non-proliferating human airway epithelial cells with a synthetic vector system. J Gene Med 2004, 6:210-221.

71. Vandenberghe L, Wilson J, Gao G: Tailoring the AAV vector capsid for gene therapy. Gene Ther 2009, 16:311-319.

72. Perabo L, Huber A, Märsch S, Hallek M, Büning H: Artificial evolution with adeno-associated viral libraries. Comb Chem High Throughput Screen 2008, 11:118-126.

73. Writer M, Hurley CA, Sarkar S, Copeman DM, Wong JB, Odlyha M, Jayne Lawrence M, Tabor AB, McAnulty RJ, Ayazi Shamlou P, Hailes HC, Hart SL: Analysis and optimization of the cationic lipid component of a lipid/ peptide vector formulation for enhanced transfection in vitro and in vivo. J Liposome Res 2006, 16:373-389.

74. Mustapa MF, Grosse SM, Kudsiova L, Elbs M, Raiber EA, Wong JB, Brain AP, Armer HE, Warley A, Keppler M, Ng T, Lawrence MJ, Hart SL, Hailes HC, Tabor $A B$ : Stabilized integrin-targeting ternary LPD (lipopolyplex) vectors for gene delivery designed to disassemble within the target cell. Bioconjugate 
Chem 2009, 20:518-532.

75. Hyde SC, Pringle IA, Abdullah S, Lawton AE, Davies LA, Varathalingam A, Nunez-Alonso G, Green AM, Bazzani RP, Sumner-Jones SG, Chan M, Li H, Yew NS, Cheng SH, Boyd AC, Davies JC, Griesenbach U, Porteous DJ, Sheppard DN, Munkonge FM, Alton EW, Gill DR: CpG-free plasmids confer reduced inflammation and sustained pulmonary gene expression. Nat Biotechnol 2008, 26:549-551.

76. Krug A, Towarowski A, Britsch S, Rothenfusser S, Hornung V, Bals R, Giese T, Engelmann $\mathrm{H}$, Endres $\mathrm{S}$, Krieg AM, Hartmann G: Toll-like receptor expression reveals CpG DNA as a unique microbial stimulus for plasmacytoid dendritic cells which synergizes with CD40 ligand to induce high amounts of IL-12. Eur I Immuno/ 2001, 31:3026-3037.

77. Strayer M, Guttentag S, Ballard P: Targeting type II and Clara cells for adenovirus-mediated gene transfer using the surfactant protein $B$ promoter. Am J Respir Cell Mol Biol 1998, 18:1-11.

78. Hendrickson B, Senadheera D, Mishra S, Bui K, Wang X, Chan B, Petersen D, Pepper K, Lutzko C: Development of lentiviral vectors with regulated respiratory epithelial expression in vivo. Am J Cell Mol Biol 2007, 37:414-423.

79. Ostrowski L, Yin W, Diggs P, Rogers T, O'Neal W, Grubb B: Expression of CFTR from a ciliated cell-specific promoter is ineffective at correcting nasal potential difference in CF mice. Gene Ther 2007, 14:1492-1501.

80. Koehler DR, Chow YH, Plumb J, Wen Y, Rafii B, Belcastro R, Haardt M, Lukacs GL, Post M, Tanswell AK, Hu J: A human epithelium-specific vector optimized in rat pneumocytes for lung gene therapy. Pediatr Res 2000, 48:184-190.

81. Gossen $\mathrm{M}, \mathrm{Bujard} \mathrm{H}$ : Tight control of gene expression in mammalian cells by tetracycline-responsive promoters. Proc Natl Acad Sci U S A 1992, 89:5547-5551.

82. Duerr J, Gruner M, Schubert S, Haberkorn U, Bujard H, Mall M: Use of a new generation reverse tetracycline transactivator system for quantitative control of conditional gene expression in the murine lung. Am J Respir Cell Mol Biol 2010, 178:1245-1256
83. Lamartina S, Silvi L, Roscilli G, Casimiro D, Simon AJ, Davies ME, Shiver JW, Rinaudo CD, Zampaglione I, Fattori E, Colloca S, Gonzalez Paz O, Laufer R, Bujard H, Cortese R, Ciliberto G, Toniatti C: Construction of an rtTA2(s)-m2/ $\mathrm{tts}(\mathrm{kid})$-based transcription regulatory switch that displays no basal activity, good inducibility, and high responsiveness to doxycycline in mice and non-human primates. Mol Ther 2003, 7:271-280.

84. Weiss Y, Tazelaar J, Gehan B, Bouwman A, Christofidou-Solomidou M, Yu Q, Raj $\mathrm{N}$, Deutschman C: Adenoviral vector transfection into the pulmonary epithelium after cecal ligation and puncture in rats. Anesthesiology 2001 95:974-982.

85. Yan Z, Zak R, Luxton G, Ritchie T, Bantel-Schaal U, Engelhardt J: Ubiquitination of both adeno-associated virus type 2 and 5 capsid proteins affects the transduction efficiency of recombinant vectors. J Virol 2002, 76:2043-2053.

86. Kida H, Mucenski M, Thitoff A, Le Cras T, Park K, Ikegami M, Müller W, Whitsett J: GP130-STAT3 regulates epithelial cell migration and is required for repair of the bronchiolar epithelium. Am J Pathol 2008, 172:1542-1554.

87. ter Horst S, Fijlstra M, Sengupta S, Walther F, Wagenaar G: Spatial and temporal expression of surfactant proteins in hyperoxia-induced neonatal rat lung injury. BMC Pulm Med 2006, 6:8.

88. Chen G, Reddy R, Newstead M, Tateda K, Kyasapura B, Standiford T: Intrapulmonary TNF gene therapy reverses sepsis-induced suppression of lung antibacterial host defense. J Immuno/ 2000, 165:6496-6503.

doi:10.1186/cc10216

Cite this article as: Devaney J, et al: Clinical Review: Gene-based therapies for ALI/ARDS: where are we now? Critical Care 2011, 15:224. 